\title{
Preparation of Quality Enriched Vermicompost and its Analysis
}

\author{
Kumar Chiranjeeb* and S. S. Prasad \\ Department of Soil Science, Dr. Rajendra Prasad Central Agricultural University, \\ Pusa, Samastipur-848125, India \\ *Corresponding author
}

\section{A B S T R A C T}

\begin{tabular}{|l|}
\hline Ke y w o r d s \\
Vermicompost, \\
$\begin{array}{l}\text { Biomass, Carbon } \\
\text { pools, Microbes }\end{array}$ \\
\hline Article Info \\
\hline $\begin{array}{l}\text { Accepted: } \\
\text { 22 June 2020 } \\
\text { Available Online: } \\
\text { 10 July 2020 }\end{array}$ \\
\hline
\end{tabular}

Enriched vermicompost preparation used Eisenia foetida vermiworm species and other additives (PSB, bacillus, rock phosphate) in it. The whole experiment was carried out at experimental station, Dr. RPCAU, Pusa and physical, chemical, enzymatic and biological properties were analyzed to ensure its quality aspect. Parameters like TN (Total nitrogen), TP (total phosphorus), TK (total potassium), MBP (Microbial biomass phosphorus), WSC(Water soluble carbon),HWSC(Hot water soluble carbon) and dehydrogenase activities increased from $0^{\text {th }}$ day to 90 days of Vermicomposting where as maximum WHC (water holding capacity) slightly decreased in case of 50\% HHW (Household waste) and $50 \%$ CD (Cow dung) combinations. The parameters such as BD (Bulk density), TOC (Total organic carbon), C: $\mathrm{N}$ ratio, MBN (Microbial biomass nitrogen), AHC (acid hydrolysable carbohydrate), $\mathrm{KMnO}_{4}$-Carbon, $\mathrm{OC}$ (Organic carbon) deceased from $0^{\text {th }}$ day to $90^{\text {th }}$ days of Vermicomposting. All functional indicators microbes (bacillus, pseudomonas, PSB, Starch hydrolyzing, cellulose hydrolyzing, azotobacter, azospirillum) and MBC (Microbial biomass carbon) increased from $0^{\text {th }}$ day to $60^{\text {th }}$ days of vemicomposting and later decreased from $60^{\text {th }}$ days to $90^{\text {th }}$ days of Vermicomposting. The recovery percentage was found highest $(63.00 \%)$ in case of $50 \% \mathrm{HHW}$ and $50 \% \mathrm{CD}$ followed by $35 \% \mathrm{HHW}$ and $65 \% \mathrm{CD}(58.33 \%)$ combinations. Among all ratios of Vermicomposting 50\% HHW and 50\% CD combination excelled in all parameters.

\section{Introduction}

Waste decomposition and its management have emerged as an alarming situation for the whole world. Waste materials not only create problems for environment as well as affect human and other animals.

The Vermicomposting has been proved successful, cost-economic, safe methods for decomposition of wastes generated from agriculture as well as households on daily basis. Vermicomposting usues vermiworm for degradation of waste materials. Vermicompost improves soil physical, chemical, biological properties as well as vermicast contains many useful enzymes likes lipases, protease, cellulose etc. vermicompost use in field is known to improve nutrient soulibilization and act as nutrient resource, thus better plant growth (Kumar et.al.2020). 
Materials and Methods

\section{Quality enriched vermicompost preparation}

The household wastes are collected from residents were kept in open (sun drying) for about 2-3 days. Then the cow dung collected from university research station (Dr. RPCAU) were processed properly and was mixed with waste materials in different ratios by weight (Table-1) and was kept in as such for lowering down of temperature as well as addition of water was also taken care of.

Then when temperature was suitable and it was partially degraded vermiworm i.e. "Eisenia foetida" were added at the rate $2 \mathrm{~kg}$ ton $^{-1}$ of substrate in 3 different bed prepared of size $10 \mathrm{ft}$. $\mathrm{x} 2 \mathrm{ft}$. $x 1.5 \mathrm{ft}$. To enrich the quality and speed up the process of composting different additives like Broth culture of Phosphorus solubilizing bacteria, and Bacillus sp. were collected from BioFertilizer Production Unit, Department of Soil Science, Tirhut College of Agriculture, Dholi and Rock Phosphate was taken from vermicompost production unit, RPCAU, Pusa.

The whole process was carried out at vermicompost experimental station of RPCAU, Pusa and phase wise collection of vermicompost were carried out at 30,60 and 90 days for quality parameters analysis using different methods. The different parameters analyzed are discussed below:-

\section{Physical parameters}

\section{Maximum water holding capacity (\%)}

The maximum water holding capacity of vermicompost was analyzed (at 30, 60 and 90 days) using Keen-Rackzowski box described by Piper (1986).

\section{Bulk Density $\left(\mathrm{Mg} \mathrm{m}^{-3}\right)$}

The bulk density in vermicompost was analyzed (at 30, 60 and 90 days) by tapping the samples in $250 \mathrm{ml}$ cylinder described by FCO (1985).

\section{Chemical Parameters}

\section{Total Organic Carbon (\%)}

The total organic carbon was analyzed by dry combustion method in muffle furnace by heating at $550^{\circ} \mathrm{C}$ described by Nelson and Sommer (1982).

\section{Microbial biomass carbon}

Microbial biomass carbon in vermicompost was analyzed by using chloroform following fumigation extraction method as described by Vance et al.,(1987). One gram vermicompost sample was taken and fumigated with ethanol free chloroform for 24 hours in a vacuum dedicator. Then $0.5 \mathrm{M} \mathrm{K}_{2} \mathrm{SO}_{4}$ was added and was shaken for 30 minutes and filter through whatman no.42 filter paper. Then the standard procedures of Vance et al., (1987) were followed and 0.45 efficiency factor was taken for calculation in case of both fumigated and non-fumigated vermicompost sample.

Microbial biomass carbon in vermicompost $\left(\mu \mathrm{g} \mathrm{g}^{-1}\right)$

$$
\mathrm{SMBC}=\quad \frac{\left(\text { Ext }_{\mathrm{f}}-\mathrm{C}_{\mathrm{uf}}\right)}{\mathrm{K}_{\mathrm{EC}}}
$$

Where, Ext $\mathrm{C}_{\mathrm{f}}=$ extractable carbon in fumigated sample

$\mathrm{C}_{\mathrm{uf}}=$ extractable carbon in unfumigated sample

$\mathrm{K}_{\mathrm{EC}}=$ efficiency factor, which is 0.45 


\section{Microbial biomass phosphorus}

0.25 gram of vermicompost samples were taken in a container and choloroform was added in it, and then kept in incubator for 24 hours. The after 24 hours both fumigated and non-fumigated samples shaken 30 minutes with $0.5 \mathrm{M} \mathrm{NaHCO}_{3}$ and the same process for absorbance reading at $660 \mathrm{~nm}$.(Brookes et al., 1982).

\section{Microbial biomass nitrogen}

One gram of vermicompost sample was taken and $20 \mathrm{ml}$ chloroform was added to fumigate and the kept in incubator for 24 hours. Another unfumigated sample was kept in refrigerator as well as 10gram sample was kept for moisture calculatons. After 24 hours both fumigated and unfumigated samples were shaken with $100 \mathrm{ml}$ of $2 \mathrm{M} \mathrm{KCl}$ for 1 hours. The standard method of Brookes et al., 1985 was followed for futher process and calculations.

\section{Microbial biomass nitrogen $\left(\mu \mathrm{g} \mathrm{g}^{-1}\right)$}

SMBN

$\frac{\text { Ext } \mathrm{N}\left(\mathrm{NH}_{4}-\mathrm{N}+\mathrm{NO}_{3}-\mathrm{N}\right)_{\mathrm{f}}-\text { Ext } \mathrm{N}\left(\mathrm{NH}_{4}-\mathrm{N}+\mathrm{NO}_{3}-\mathrm{N}\right)_{\mathrm{uf}}}{\mathrm{K}_{\mathrm{n}}}$

Where,

Ext $\mathrm{N}_{\mathrm{f}}=$ extractable nitrogen in fumigated sample

Ext $\mathrm{N}_{\mathrm{uf}}=$ extractable nitrogen in unfumigated sample

$\mathrm{NH}_{4}-\mathrm{N}=$ extractable ammonical nitrogen

$\mathrm{NO}_{3}-\mathrm{N}=$ extractable nitrate nitrogen

$\mathrm{Kn}=$ efficiency of extraction of microbial biomass nitrogen $(0.50)$

\section{Water soluble carbon (cold and hot water extractable)}

One gram of vermicompost sample was taken and $20 \mathrm{ml}$ deionised water was added it and sealed with para film at $105 \mathrm{oC}$ in heating block for 45-60 mins, centrigused at 3500 rpm for 30 mins. The the filtrate was processed further using ferroin indicator according to Mc Gill et al.,1986 and Ghani et al.,2003.

\section{Acid hydrolysable carbohydrate}

0.5 gram of vermicompost sample was hyfrolyzed for 24 hours with $24 \mathrm{~N} \mathrm{H} 2 \mathrm{SO} 4$ addition and steam bath at about $100 \mathrm{OC}$. The filtrate was neutralized with $6 \mathrm{~N} \mathrm{NaOH}$ to $\mathrm{pH}$ 6.8 , then left for cooling and centrifused at $10000 \mathrm{rpm}$ for 10 minutes. $5 \mathrm{ml}$ hydrolysate was taken in a test tube and $10 \mathrm{ml} 0.2 \%$ anthrone was added and geen color intensity was read ar $625 \mathrm{~nm}$ (Chesire and Mundie,1966).

\section{$\mathrm{KMnO}_{4}$-carbon}

0.5 gram vermicompost was taken in $50 \mathrm{ml}$ centrifuse tube and $30 \mathrm{ml}$ of $20 \mathrm{Mm}$ permanganate solution was added the shaken for 15 minutes and centrifused at $2000 \mathrm{rpm}$ for 5 mins. $2 \mathrm{ml}$ filtrate was taken in $50 \mathrm{ml}$ volumetric flask and reading was taken at 560nm (Blair et al., 1995).

$$
\operatorname{POSC}\left(\mathrm{mg} \mathrm{kg}^{-1}\right)=\frac{(\mathrm{B}-\mathrm{S}) \times 50 \times 30 \times 1000 \times 9}{2 \times 1000 \times 3}
$$

Where,

$\mathrm{B}=$ conc. Of $\mathrm{KMnO}_{4}$ in blank (milimoles)

$\mathrm{S}=$ conc. Of $\mathrm{KMnO}_{4}$ in sample (milimoles)

$50 / 2=$ dilution factor

$9=\mathrm{mg}$ of carbon oxidized by $1 \mathrm{mM}$ of $\mathrm{KMnO}_{4}$

\section{Active organic carbon}

50 mili gram of sample was taken and the standard methods was followed (Walkey and Black-1934) as described in Black (1965). 
Organic carbon $(\%)=\frac{10(\mathrm{~B}-\mathrm{S}) \times 0.003 \times 100}{\mathrm{~B} \times \text { weight of sample }(\mathrm{g})}$

Where,

$\mathrm{B}=$ titration value of blank

$\mathrm{S}=$ titration value of sample

\section{Dehydrogenase enzyme}

0.5 gram vermicompost sample was taken in $15 \mathrm{ml}$ capacity test tube and $0.2 \mathrm{ml}$ of $3 \% \%$ triphenyl tetrazolium chloride (TTC) was added along with $0.5 \mathrm{ml}$ glucose solution. Then it was incubated at $280 \mathrm{C}$ for 24 hours, after that $10 \mathrm{ml}$ methanol was added and allowed to stand for 6 hours. The absorbance of pink color formed was read with spectrophotometer at $485 \mathrm{~nm}$ wavelength (Klein et al., 1971).

\section{Recovery of vermicompost}

Recovery of vermicompost was calculated on the basis of the final dry weight obtained from each windrows taken out of total dry matter of substrate was used for the decomposition (Sharma, 2015).

Recovery of vermicompost (\%) =

$\frac{\text { Dry weight of vermicompost }}{\text { Dry weight of substrata }} \times 100$

\section{Functional indicator microbes}

One gram of vermicompost sample was taken in $99 \mathrm{ml}$ water in $500 \mathrm{ml}$ flask and serial dilution was made up to $10^{-5}$. $0.5 \mathrm{ml}$ of sample was taken from $10^{-5}$ dilution was spread in petri plate along with different media for different microbes studies like Bacillus, Pseudomonas, Azotobacter, Azospirillum, PSB, Cellulose hydrolyzing Bacteria, starch hydrolyzing microbes as described further in soil analysis section (3.4) by Schmidt and Coldwell(1967).

\section{Results and Discussion}

\section{Maximum Water Holding Capacity (\%)}

The maximum water holding capacity as shown in the table-2 showed the variation from 33.3 to $20.3 \%, 27.0$ to $20.7 \%$ and 26.3 $\%$ to $19.4 \%$ in case of $35 \%$ HHW + CD $65 \%$, HHW 50\%+CD 50\% and HHW 65\% + CD $35 \%$ respectively at 30 days, 60 days and 90days of composting.

\section{Bulk density $\left(\mathrm{Mg} \mathrm{m}^{-3}\right)$}

The bulk density (table-2) decreased from 1.3 $\mathrm{Mg} \mathrm{m}^{-3}$ to $0.9 \mathrm{Mg} \mathrm{m}^{-3}, 1.1 \mathrm{Mg} \mathrm{m}^{-3}$ to $0.8 \mathrm{Mg}$ $\mathrm{m}^{-3}$ and $1.7 \mathrm{Mg} \mathrm{m}^{-3}$ to $1.3 \mathrm{Mg} \mathrm{m}^{-3}$ in case of in case of $35 \% \mathrm{HHW}+\mathrm{CD} 65 \%$, HHW $50 \%$ $+\mathrm{CD} 50 \%$ and HHW $65 \%+\mathrm{CD} 35 \%$, respectively. The decreased bulk density observed in all three types of vermicompost as the days progress towards completion, this might be due to increase in the pore spaces in the mature vermicompost.

\section{Total organic carbon (\%)}

The total organic carbon (Table-3) decreased from 30 days up to the 90 days during the preparation of vermicompost, shown in table3. The Total organic carbon at 30,60 and 90 days were $40 \%, 38.40 \%, 36.00 \%$ for vermicompost $65 \% \mathrm{HHW}+35 \% \mathrm{CD}$, similarly $37.60 \%, 35.10 \%, 34.40 \%$ for vermicompost $50 \% \mathrm{HHW}+50 \% \mathrm{CD}$ and $37.20 \%, 36.10 \%, 35.20 \%$ for vermicompost $35 \% \mathrm{HHW}+65 \% \mathrm{CD}$.

The decrease in total organic carbon was seen in all three types of vermicompost as the days progress towards completion of it.

The results showed the decrement in the total organic carbon content with vermicomposting and it might be due to the loss of organic carbon as carbon dioxide through the 
increased microbial respiration which led to the increase in total nitrogen content. The part of carbon assimilated by microbes as food source for energy and thus increasing microbial biomass carbon and decomposing organic matter (Garg and Kaushik, 2004 and Pattnaik and Reddy, 2010) and other part lost as carbon dioxide to the environment.

\section{Total nitrogen $(\%)$}

The Total nitrogen increased from 30 days up to the 90 days during the preparation of vermicompost as shown in table-3. The total nitrogen at 30, 60 and 90 days were $1.49 \%$, $1.53 \%$ and $1.91 \%$ for vermicompost $35 \%$ HHW + $65 \%$ CD, similarly $1.69 \%, 2.06 \%$ and $2.40 \%$ for vermicompost $50 \% \mathrm{HHW}+$ $50 \% \mathrm{CD}$ and $2.23 \%, 2.27 \%, 2.30 \%$ for vermicompost $65 \% \mathrm{HHW}+35 \% \mathrm{CD}$.

The vermicompost of ratio 50:50 of household waste to cow dung ratio recorded highest total nitrogen at 30 and 60 days (1.69 $\%, 2.06 \%$ ) and also in 90 days recorded higher than vermicompost having ratio 35:65. The vermicompost of ratio 50:50 household waste to cow dung recorded highest total nitrogen $(2.40 \%)$ at 90 days followed by the vermicompost (65:35).

In all three vermicompost total nitrogen content increased from 30 days to 90 days of vermicomposting. This is might be due to mineralization of organic matter (Nath et al., 2009). During vermicomposting nitrogen released from dead tissues and metabolic products of earthworm (Araujo et al., 2004). The loss of organic carbon might have added nitrogen in form of growth stimulant hormones and other nitrogenous excretory substances (Tripathi and Bhardwaj, 2004).

\section{TOC: Total nitrogen ratio}

The ratio of total organic carbon to total nitrogen $(\mathrm{C}: \mathrm{N}$ ratio) is considered the best indices for compost maturity (table-3). The C: $\mathrm{N}$ ratio decreased from 30 days of vermicomposting to 90 days of vermicomposting in all the three proportions of household waste and cow dung. The variations in the $\mathrm{C}$ : $\mathrm{N}$ ratio ranged from 25.00 to 18.43 for the $35: 65$ ratio of household waste and cow dung vermicompost, 22.30 to 14.42 for 50:50 ratio vermicompost and 18.00 to 15.65 for $65: 35$ ratio of vermicompost.

The vermicompost of ratio 50:50 recorded highest $\mathrm{C}$ : $\mathrm{N}$ ratio at 90 days i.e. 14.42 followed by the vermicompost of ratio 65:35 i.e. 15.65 .

The decrease in the $\mathrm{C}: \mathrm{N}$ ratio might be due to the respirartory activity of earthworms and microbes present and increase in the total nitrogen by mineralization of organic matter and addition of other nitrogenous wastes (Jadia and Fulekar, 2008). The combustion of organic carbon during respiration and addition of plant derived organic substances and also microbial decomposition contributes to composting event (Chaudhuri et al., 2000). The addition of earthworms also might have decreased C: N ratio (Elvira et al., 1996).

\section{Total phosphorus (\%)}

The total phosphorus increased from 30 days up to the 90 days during the Preparation of vermicompost as shown in the table- 4 . The Total phosphorus at 30,60 and 90 days were $0.36 \%, 0.84 \%$ and $1.13 \%$ for vermicompost $65 \% \mathrm{HHW}+35 \% \mathrm{CD}, 0.31 \%, 1.00 \%$ and $1.34 \%$ for vermicompost $50 \% \mathrm{HHW}+50 \%$ $\mathrm{CD}$ and $0.29 \%, 0.81 \%$ and $1.12 \%$ for vermicompost $35 \% \mathrm{HHW}+65 \% \mathrm{CD}$.

The vermicompost of ratio 50:50 of household waste to cow dung ratio recorded highest total phosphorus content at 60 days $(1.00 \%)$ and also at 90 days recorded higher than vermicompost ratio 35:65. The 
vermicompost of ratio 50:50 household waste to cow dung ratio recorded highest total phosphorus content $(1.34 \%)$ at 90 days followed by $1.13 \%$ in the vermicompost 65:35.

The increase in the total phosphorus was seen in all types of vermicompost as the days progress towards completion of Vermicomposting, might be due to mineralization and mobilization of phosphorus due to the microbial activities and phosphatase activity residing inside earthworm guts (Krishnamoorthy, 1990). The passage of organic substances through the guts of earthworms resulted in conversion of organically bound insoluble phosphorus into plant available soluble form of phosphorus by the activities of phosphatases and other phosphorus solubilizing organisms present in worm casts.

\section{Total potassium (\%)}

The total potassium increased from 30 days up to the 90 days during the preparation of vermicompost as described in the table-4.The total potassium at 30,60 and 90 days were $1.23 \%, 1.33 \%$ and $1.37 \%$ for vermicompost $65 \% \mathrm{HHW}+35 \% \mathrm{CD}, 1.41 \%, 1.63 \%$ and $1.79 \%$ for vermicompost $50 \% \mathrm{HHW}+50 \%$ $\mathrm{CD}$ and $1.20 \%, 1.42 \%$ and $1.66 \%$ for vermicompost $35 \% \mathrm{HHW}+65 \% \mathrm{CD}$.

The vermicompost of ratio 50:50 of household waste to cow dung ratio recorded highest total potassium content at 30 day, 60 days $(1.41 \%, 1.63 \%)$ and also in 90 days, it recorded higher than vermicompost 35:65. The vermicompost of ratio 50:50 household waste to cow dung ratio recorded highest results for total potassium content $(1.79 \%)$ at 90 days followed by $1.66 \%$ in the vermicompost 35:65.

The increase in the total potassium was noted in all three types of vermicompost as the days progress towards maturity, it might be due increase in mineralization of potassium due to enhanced microbial activity as well as enzymatic activities in earthworm guts (Parthasarathi and Ranganathan, 2000).

\section{Microbial biomass carbon $\left(\mu \mathrm{g} \mathrm{g}^{-1}\right)$}

The microbial biomass carbon increased from 30 days up to the 90 days during the preparation of vermicompost (table-5). The microbial biomass carbon at 30,60 and 90 days were $196 \mu \mathrm{g} \mathrm{g}^{-1}, 285 \mu \mathrm{g} \mathrm{g}^{-1}, 270 \mu \mathrm{g} \mathrm{g}^{-1}$ for vermicompost $65 \% \mathrm{HHW}+35 \% \mathrm{CD}$, $278 \mu \mathrm{g} \mathrm{g}^{-1}, 322 \mu \mathrm{g} \mathrm{g} \mathrm{g}^{-1}, 298 \mu \mathrm{g} \mathrm{g}^{-1}$ for vermicompost $50 \% \mathrm{HHW}+50 \% \mathrm{CD}$ and $266 \mu \mathrm{g} \mathrm{g} \mathrm{g}^{-1}, 308 \mu \mathrm{g} \mathrm{\textrm {g } ^ { - 1 }}, 289 \mu \mathrm{g} \cdot \mathrm{g}^{-1}$ for vermicompost $35 \% \mathrm{HHW}+65 \% \mathrm{CD}$.

The vermicompost of ratio 50:50 of household waste to cow dung ratio recorded highest microbial biomass carbon content at 30 day and 60 days $\left(278 \mu \mathrm{g} \mathrm{g}^{-1}, 322 \mu \mathrm{g} \mathrm{g}^{-1}\right)$ and also in 90 days it recorded higher than vermicompost ratio 35:65. The vermicompost of ratio 50:50 household waste to cow dung ratio recorded higher microbial biomass carbon content $\left(298 \mu \mathrm{g} \mathrm{g}^{-1}\right)$ at 90 days followed by the vermicompost 35:65.

The increase in the microbial biomass carbon was recorded in all three types of vermicompost as the days progress towards completion, this might be possible due to adequate availability of organic matter for the increased microbial activities thus elevating their biomass and microbial biomass carbon.

\section{Microbial biomass nitrogen $\left(\mu \mathrm{g} \mathrm{g}^{-1}\right)$}

The Microbial biomass nitrogen increased from 30 days up to the 90 days during the preparation of vermicompost, (table-5). The microbial biomass nitrogen at 30,60 and 90 days were $192 \mu \mathrm{g} \mathrm{g}^{-1}, 190 \mu \mathrm{g} \mathrm{g}^{-1}, 187 \mu \mathrm{g} \mathrm{g}^{-1}$ for vermicompost $65 \% \mathrm{HHW}+35 \% \mathrm{CD}, 214$ 
$\mu \mathrm{g} \mathrm{g}^{-1}, 208 \mu \mathrm{g} \mathrm{g}^{-1}, 198 \mu \mathrm{g} \mathrm{g}^{-1}$ for vermicompost $50 \% \mathrm{HHW}+50 \% \mathrm{CD} 200 \mu \mathrm{g} \mathrm{g}^{-1}, 196 \mu \mathrm{g} \mathrm{g}^{-1}$ and193 $\mu \mathrm{g} \mathrm{g}^{-1}$ for vermicompost $35 \% \mathrm{HHW}$ $+65 \% \mathrm{CD}$.

The vermicompost of ratio (50:50) of household waste to cow dung ratio recorded highest microbial biomass carbon content at 30 day and 60 days $\left(278 \mu \mathrm{g} \mathrm{g}^{-1}, 322 \mu \mathrm{g} \mathrm{g}^{-1}\right)$ and also in 90 days it recorded higher than vermicompost ratio 35:65. The vermicompost of household waste to cow dung ratio 50:50 recorded highest microbial biomass carbon content $\left(298 \mu \mathrm{g} \mathrm{g}^{-1}\right)$ at 90 days followed by the vermicompost 35:65.

The increase in the microbial biomass nitrogen was recorded in all three types of vermicompost as the days progress towards completion of Vermicomposting. The increase in organic matter content increased microbial activities there by increased the nitrogen assimilation and contributed to biomass nitrogen.

\section{Microbial biomass phosphorus $\left(\mu \mathrm{g} \mathrm{g}^{-1}\right)$}

The microbial biomass phosphorus increased from 30 days up to the 90 days during the preparation of vermicompost (table-5). The Microbial biomass Phosphorus at 30, 60 and 90 days were $14.00 \mu \mathrm{g} \mathrm{g}^{-1}, 14.25 \mu \mathrm{g} \mathrm{g}^{-1}, 14.50$ $\mu \mathrm{g} \mathrm{g}^{-1}$ for vermicompost $(65 \% \mathrm{HHW}+35 \%$ CD), $13.90 \mu \mathrm{g} \mathrm{g}^{-1}, 17.00 \mu \mathrm{g} \mathrm{g}^{-1}$ and $17.80 \mu \mathrm{g}$ $\mathrm{g}^{-1}$ for vermicompost $(50 \% \mathrm{HHW}+50 \% \mathrm{CD})$ and $13.30 \mu \mathrm{g} \mathrm{g}^{-1}, 16.00 \mu \mathrm{g} \mathrm{g}^{-1}, 16.30 \mu \mathrm{g} \mathrm{g}^{-1}$ and for vermicompost (35\% HHW+65\% CD).

The vermicompost of ratio 50:50 of household waste to cow dung recorded highest microbial biomass phosphorus content at 30 day and 90 days $\left(13.90 \mu \mathrm{g} \mathrm{g}^{-1}, 17.00 \mu \mathrm{g}\right.$ $\left.\mathrm{g}^{-1}\right)$ and also increased in 60 days $(17.00 \mu \mathrm{g} \mathrm{g}$ $\left.{ }^{1}\right)$ thus it recorded higher than vermicompost ratio $(35: 65)$. The vermicompost of ratio
(50:50) household waste to cow dung ratio recorded highest results for microbial biomass phosphorus content $\left(17.80 \mu \mathrm{g} \mathrm{g}^{-1}\right)$ at 90 days followed by the vermicompost (35:65).

The increase in the microbial biomass phosphorus was seen in all types of vermicompost as the days progress towards completion, might be attributed be due to organic matter content for the microbial activities thus increased phosphorus assimilation by the microbes thus increased microbial biomass phosphorus.

\section{Water soluble carbon $\left(\mathrm{mg} \mathrm{g}^{-1}\right)$}

The water soluble carbon increased from 30 days up to the 90 days during the preparation of vermicompost (table-6). The water soluble carbon at 30, 60 and 90 days were $0.048 \mathrm{mg}$

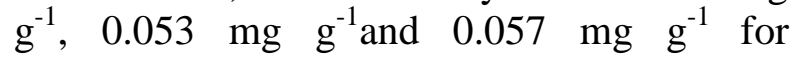
vermicompost $65 \% \mathrm{HHW}+35 \% \mathrm{CD}, 0.071$ $\mathrm{mg} \mathrm{g}^{-1}, \quad 0.077 \mathrm{mg} \cdot \mathrm{g}^{-1}, 0.081 \mathrm{mg} \mathrm{g}^{-1}$ for vermicompost $50 \% \mathrm{HHW}+50 \% \mathrm{CD}$ and $0.059 \mathrm{mg} \mathrm{g}^{-1}, 0.063 \mathrm{mg} \mathrm{g}^{-1}$ and $0.066 \mathrm{mg} \mathrm{g}^{-1}$ for vermicompost $35 \% \mathrm{HHW}+65 \% \mathrm{CD}$.

The vermicompost of ratio 50:50 of household waste to cow dung ratio recorded highest water soluble carbon content at 30 day and 60 days $\left(0.071 \mathrm{mg} \mathrm{g}^{-1}, 0.077 \mathrm{mg} \mathrm{g}^{-1}\right)$ and also increase in 90 days $\left(0.081 \mathrm{mg} \mathrm{g}^{-1}\right)$, thus it recorded higher than vermicompost ratio 35:65. The vermicompost of household waste to cow dung ratio 50:50 recorded higher water soluble carbon content $\left(0.081 \mathrm{mg} \mathrm{g}^{-1}\right)$ at 90 days followed by the vermicompost 35:65.

The increase in the water soluble carbon was noticed in all three types of vermicompost towards its completion of it. This observation recorded with water soluble carbon might be due to passing of substrate to the guts of epigeic earthworm increased water soluble carbon. 


\section{Hot-water soluble carbon ( $\left.\mathrm{mg} \mathrm{g}^{-1}\right)$}

The hot-water soluble carbon increased from 30 days up to the 90 days during the preparation of vermicompost (table-6). The hot-water soluble carbon at 30,60 and 90 days were $0.426 \mathrm{mg} \mathrm{g}^{-1}, 0.436 \mathrm{mg} \mathrm{g}^{-1}, 0.471$ $\mathrm{mg} \mathrm{g}^{-1}$ for vermicompost $65 \% \mathrm{HHW}+35 \%$ $\mathrm{CD}, 0.530 \mathrm{mg} \mathrm{g}^{-1}, 0.542 \mathrm{mg} \mathrm{g}^{-1}, 0.550 \mathrm{mg} \mathrm{g}^{-1}$ for vermicompost $50 \% \mathrm{HHW}+50 \% \mathrm{CD}$ and $0.508 \mathrm{mg} \mathrm{g}^{-1}, 0.520 \mathrm{mg} \mathrm{g}^{-1}$ and $0.532 \mathrm{mg} \mathrm{g}^{-1}$ for vermicompost $35 \% \mathrm{HHW}+65 \% \mathrm{CD}$.

The vermicompost prepared from equal proportion of household waste and cow dung ratio recorded highest hot-water soluble carbon content at 30 day and 60 days $(0.530$ $\left.\mathrm{mg} \mathrm{g}^{-1}, 0.542 \mathrm{mg} \mathrm{g}^{-1}\right)$ and also increased in 90 days $\left(0.550 \mathrm{mg} \mathrm{g}^{-1}\right)$, thus it recorded higher than vermicompost ratio (35:65). The vermicompost of ratio (50:50) household waste to cow dung ratio recorded highest results for hot-water soluble carbon content $\left(0.550 \mathrm{mg} \mathrm{g}^{-1}\right)$ at 90 days followed by the vermicompost (35:65).

The increase in the hot-water soluble carbon was recorded with increase in vermicomposting period in all three types of vermicompost, could be due to increase in the mineralization of organic carbon contents due to increased microbial activities.

\section{Acid hydrolysable carbohydrate ( $\mathrm{mg} \mathrm{kg}^{-1}$ )}

The acid hydrolysable carbohydrate content of three vermicomposting windrows presented in the table- 6 revealed progressive increase upto 60 days and decreased slightly at 90 days. The acid hydrolysable carbohydrate at 30,60 and 90 days were $22.06 \mathrm{mg} \mathrm{kg}^{-1}, 26.06 \mathrm{mg} \mathrm{kg}^{-1}$ and $24.06 \mathrm{mg}$ $\mathrm{kg}^{-1}$ for vermicompost $65 \% \mathrm{HHW}+35 \%$ $\mathrm{CD}, 80.21 \mathrm{mg} \mathrm{kg}^{-1}, 85.21 \mathrm{mg} \mathrm{kg}^{-1,} 83.21 \mathrm{mg}$ $\mathrm{kg}^{-1}$ for vermicompost $50 \% \mathrm{HHW}+50 \%$ $\mathrm{CD}$ and $40.22 \mathrm{mg} \mathrm{kg}^{-1}, 41.55 \mathrm{mg} \mathrm{kg}^{-1}$ and
$40.88 \mathrm{mg} \mathrm{kg}^{-1}$ for vermicompost $35 \% \mathrm{HHW}$ $+65 \% \mathrm{CD}$.

The vermicompost obtained from household waste and cow dung ratio 50:50 recorded highest acid hydrolysable carbohydrate content at 30 day, 60 days $\left(80.21 \mathrm{mg} \mathrm{kg}^{-1}\right.$, $\left.85.21 \mathrm{mg} \mathrm{kg}^{-1}\right)$ and in 90 days $\left(83.17 \mathrm{mg} \mathrm{kg}^{-}\right.$ $\left.{ }^{1}\right)$, thus it recorded higher than vermicompost ratio 35:65.

The increase in the acid hydrolysable carbohydrate with progression period of vermicomposting could be due to increase in the microbial activities and used the carbohydrate as their energy sources

\section{$\mathrm{KMnO}_{4^{-}}$carbon $\left(\mathrm{g} \mathrm{kg}^{-1}\right)$}

The $\mathrm{KMnO}_{4}$-carbon decreased from 30 days to the 90 days during the preparation of vermicompost (table-7). The $\mathrm{KMnO}_{4}$-carbon at 30,60 and 90 days were $5.56 \mathrm{~g} \mathrm{~kg}^{-1}, 5.06 \mathrm{~g}$ $\mathrm{kg}^{-1}, 4.75 \mathrm{~g} \mathrm{~kg}^{-1}$ for vermicompost $65 \%$ $\mathrm{HHW}+35 \% \mathrm{CD}, 6.25 \mathrm{~g} \mathrm{~kg}^{-1}, 5.97 \mathrm{~g} \mathrm{~kg}^{-1}, 5.42$ $\mathrm{g} \mathrm{kg}^{-1}$ for vermicompost $50 \% \mathrm{HHW}+50 \%$ $\mathrm{CD}$ and $5.79 \mathrm{~g} \mathrm{~kg}^{-1}, 5.32 \mathrm{~g} \mathrm{~kg}^{-1}, 5.01 \mathrm{~g} \mathrm{~kg}^{-1}$ for vermicompost $35 \% \mathrm{HHW}+65 \% \mathrm{CD}$.

The vermicompost prepared from household waste and cow dung ratio 50:50 recorded highest $\mathrm{KMnO}_{4}$ - carbon content at 30 day and 60 days $\left(6.25 \mathrm{~g} \mathrm{~kg}^{-1}, 5.97 \mathrm{~g} \mathrm{~kg}^{-1}\right)$ while decreased in 90 days $\left(5.45 \mathrm{~g} \mathrm{~kg}^{-1}\right)$, thus it recorded highest than vermicompost ratio 35:65 and 65: 35 .

The decrease in the $\mathrm{KMnO}_{4}$-carbonwas seen in all three types of vermicompost could be due to increase in the microbial population used carbon as their food source.

\section{Organic carbon $\left(\mathrm{g} \mathrm{kg}^{-1}\right)$}

The organic carbon content decreased from 30 days to the 90 days during the preparation 
of vermicompost (table-7). The organic carbon at 30, 60 and 90 days were $175.80 \mathrm{~g}$ $\mathrm{kg}^{-1}, \quad 116.40 \mathrm{~g} \mathrm{~kg}^{-1}, \quad 105.00 \mathrm{~g} \mathrm{~kg}^{-1}$ for vermicompost $65 \% \mathrm{HHW}+35 \% \mathrm{CD}$, $186.20 \mathrm{~g} \mathrm{~kg}^{-1}, 129.10 \mathrm{~g} \mathrm{~kg}^{-1}, 117.00 \mathrm{~g} \mathrm{Kg}^{-1}$ for vermicompost $50 \% \mathrm{HHW}+50 \% \mathrm{CD}$ and $178.40 \mathrm{~g} \mathrm{~kg}^{-1}, 103.70 \mathrm{~g} \mathrm{Kg}^{-1}, 97.60 \mathrm{~g} \mathrm{Kg}^{-1}$ and for vermicompost $35 \% \mathrm{HHW}+65 \% \mathrm{CD}$.

The vermicompost of ratio (50:50) of household waste to cow dung ratio recorded highest Organic carbon content at 30 day and 60 days $\left(186.20 \mathrm{~g} \mathrm{~kg}^{-1}, 129.10 \mathrm{~g} \mathrm{~kg}^{-1}\right)$, also decreased in 90 days $\left(117.00 \mathrm{~g} \mathrm{~kg}^{-1}\right)$, as so it recorded higher than vermicompost ratio (65:35).

The increase in the organic carbon was seen in all stages in three types of vermicompost as the days progress towards completion of it, could be attributed due to passing of substrate through the guts of earthworm increased the microbial activities and better decomposition led to increase in organic carbon content.

\section{Dehydrogenase activity ( $\mu \mathrm{g}$ TPF $\mathrm{g}^{-1}$ soil $\mathrm{hr}^{-}$ 1)}

The dehydrogenase activity increased from 30 days upto 90 days during the preparation of vermicompost (table-7). The dehydrogenase activity at 30,60 and 90 days were $6.42 \mu \mathrm{g}$ TPF g ${ }^{-1}$ soil $\mathrm{hr}^{-1}, 6.92 \mu \mathrm{g}_{\text {TPF g }}{ }^{-1}$ soil hr ${ }^{-1}, 7.12$ $\mu \mathrm{g}$ TPF $\mathrm{g}^{-1}$ soil $\mathrm{hr}^{-1}$ for vermicompost $65 \%$ $\mathrm{HHW}+35 \% \mathrm{CD}, 8.00 \mu \mathrm{g}$ TPF $\mathrm{g}^{-1}$ soil $\mathrm{hr}^{-1}$, $8.42 \mu \mathrm{g}$ TPF g ${ }^{-1}$ soil hr ${ }^{-1}, 8.96 \mu \mathrm{g}$ TPF g ${ }^{-1}$ soil $\mathrm{hr}^{-1}$ for vermicompost $50 \% \mathrm{HHW}+50 \% \mathrm{CD}$ and $6.99 \mu \mathrm{g}$ TPF g $\mathrm{g}^{-1}$ soil $\mathrm{hr}^{-1}, 7.31 \mu \mathrm{g}$ TPF g ${ }^{-1}$ soil $\mathrm{hr}^{-1}$ and $7.82 \mu \mathrm{g}$ TPF $\mathrm{g}^{-1}$ soil $\mathrm{hr}^{-1}$ for vermicompost $35 \% \mathrm{HHW}+65 \% \mathrm{CD}$.

The vermicompost of ratio 50:50 household waste and cow dung ratio recorded highest dehydrogenase activity at 30 day, 60 days $\left(8.00 \mu \mathrm{g}\right.$ TPF $\mathrm{g}^{-1}$ soil $\mathrm{hr}^{-1}, 8.42 \mu \mathrm{g}$ TPF $\mathrm{g}^{-1}$ soil $\left.\mathrm{hr}^{-1}\right)$ and in 90 days (8.96 $\mu \mathrm{g}$ TPF $\mathrm{g}^{-1}$ soil hr$\left.{ }^{-1}\right)$.
The increase in the dehydrogenase activity might be due to increased microbial activity during the progressive period of vermicomposting increased the dehydrogenase activity.

\section{Bacillus count (x $10^{7}$ c.f.u. $\mathrm{g}^{-1}$ dry soil)}

The bacillus population increased from 30 days upto the 60 days during the preparation of vermicompost (table-8). Bacillus population at 30,60 and 90 days were 34.00 x $10^{7}$ c.f.u. $\mathrm{g}^{-1}$ dry soil, $33.80 \times 10^{7}$ c.f.u. $\mathrm{g}^{-1}$ dry soil, $28.00 \times 10^{7}$ c.f.u. $\mathrm{g}^{-1}$ dry soil for vermicompost $65 \% \mathrm{HHW}+35 \% \mathrm{CD}, 35.10 \mathrm{x}$ $10^{7}$ c.f.u. $\mathrm{g}^{-1}$ dry soil, $37.00 \times 10^{7}$ c.f.u. $\mathrm{g}^{-1}$ dry soil, $36.00 \times 10^{7}$ c.f.u. $\mathrm{g}^{-1}$ dry soil for vermicompost $50 \% \mathrm{HHW}+50 \% \mathrm{CD}$ and $35.30 \times 10^{7}$ c.f.u. $\mathrm{g}^{-1}$ dry soil, $34.60 \times 10^{7}$ c.f.u. $\mathrm{g}^{-1}$ dry soil, $31.10 \times 10^{7}$ c.f.u. $\mathrm{g}^{-1}$ dry soil for vermicompost $35 \% \mathrm{HHW}+65 \%$ CD.

The vermicompost prepared from household waste and cow dung ratio 50:50 recorded highest bacillus population increasing at all three samplings at 30, 60, 90 days with slightly decrease in population at 90 days

The increase in the Bacillus population was observed from 30 days to 60 days and then decreased at 90 days in all three types of vermicompost, might be due to increase in the organic matter content increased microbial populations in initial stages but in later stage the heavy depletion of organic matter content decreased microbial population.

Pseudomonas count (x $10^{7}$ c.f.u. $g^{-1}$ dry
soil)

The Pseudomonas population increased from 30 days to 60 days and decreased slightly at 90 days during the preparation of vermicompost (table-8). The pseudomonas population at 30,60 and 90 days were 27.00 
$10^{7}$ c.f.u. $\mathrm{g}^{-1}$ dry soil, $28.80 \times 10^{7}$ c.f.u. $\mathrm{g}^{-1}$ dry soil, $23.10 \times 10^{7}$ c.f.u. $\mathrm{g}^{-1}$ dry soil for vermicompost $65 \% \mathrm{HHW}+35 \% \mathrm{CD}, 29.00 \mathrm{x}$ $10^{7}$ c.f.u. $\mathrm{g}^{-1}$ dry soil, $33.00 \times 10^{7}$ c.f.u. $\mathrm{g}^{-1}$ dry soil, $30.50 \times 10^{7}$ c.f.u. $\mathrm{g}^{-1}$ dry soil for vermicompost $50 \% \mathrm{HHW}+50 \% \mathrm{CD}$ and $27.90 \times 10^{7}$ c.f.u. $\mathrm{g}^{-1}$ dry soil, $29.50 \times 10^{7}$ c.f.u. $\mathrm{g}^{-1}$ dry soil and $27.50 \times 10^{7}$ c.f.u. $\mathrm{g}^{-1}$ dry soil and for vermicompost $35 \% \mathrm{HHW}+65$ $\% \mathrm{CD}$.

The vermicompost of ratio 50:50 of household waste to cow dung ratio recorded highest Pseudomonas population at 30 day, 60 days $\left(29.00 \times 10^{7}\right.$ c.f.u. $\mathrm{g}^{-1}$ dry soil, $33.00 \mathrm{x}$ $10^{7}$ c.f.u. $\mathrm{g}^{-1}$ dry soil) and decreased at 90 days $\left(30.50 \times 10^{7}\right.$ c.f.u. $\mathrm{g}^{-1}$ dry soil) and recorded highest population count than vermicompost ratio $35: 65$ and $65: 35$ vermicompost ratio.

The increase in the Pseudomonas population was seen from 30 days to 60 days and then decreased up to 90 days in all three types of vermicompost as the days progress towards completion, might be due to availability of organic matter at initial days of vermicomposting and then decline in organic matter was noticed in final days of vermicomposting.

Phosphate solubilizing bacteria (x $10^{7}$ c.f.u. $\mathrm{g}^{-1}$ dry soil)

The Phosphate solubilizing bacteria increased from 30 days upto the 60 days during the preparation of vermicompost and decreased in later stages (table-8).The phosphate solubilizing bacteria at 30,60 and 90 days were $30.00 \times 10^{7}$ c.f.u. $\mathrm{g}^{-1}$ dry soil, $34.20 \mathrm{x}$ $10^{7}$ c.f.u. $\mathrm{g}^{-1}$ dry soil, $31.10 \times 10^{7}$ c.f.u. $\mathrm{g}^{-1}$ dry soil for vermicompost $65 \% \mathrm{HHW}+35 \%$ CD, 31.70 (x $10^{7}$ c.f.u. $\mathrm{g}^{-1}$ dry soil), $36.30 \mathrm{x}$ $10^{7}$ c.f.u. $g^{-1}$ dry soil, $35.00 \times 10^{7}$ c.f.u. $g^{-1}$ dry soil for vermicompost $50 \% \mathrm{HHW}+50 \%$ $\mathrm{CD}$ and $32.90 \times 10^{7}$ c.f.u. $\mathrm{g}^{-1}$ dry soil, $34.90 \mathrm{x}$
$10^{7}$ c.f.u. $\mathrm{g}^{-1}$ dry soil) and $30.50 \times 10^{7}$ c.f.u. $\mathrm{g}^{-1}$ dry soil and for vermicompost $35 \%$ $\mathrm{HHW}+65 \% \mathrm{CD}$.

The vermicompost of ratio 50:50 of household waste to cow dung ratio recorded highest phosphate solubilizing bacteria at 30 days and 60 days $\left(31.70 \times 10^{7}\right.$ c.f.u. $g^{-1}$ dry soil, $36.30 \times 10^{7}$ c.f.u. $\mathrm{g}^{-1}$ dry soil) and decreased in 90 days $\left(35.00 \times 10^{7}\right.$ c.f.u. $\mathrm{g}^{-1}$ dry soil), thus it recorded higher than vermicompost ratio 35:65.

The increase in the Phosphate solubilizing bacteria count was seen from 30 days to 60 days and then decreased up to 90 days in all types of vermicompost as the days progress towards completion of it, might be due to increase in the organic matter content increased microbial populations in initial stages in later stage the heavy depletion of organic matter content decreased microbial population.

\section{Starch hydrolyzing microbes (x $10^{7}$ c.f.u. $g^{-}$ ${ }^{1}$ dry soil)}

The Starch hydrolyzing microbes increased from 30 days upto 60 days during the preparation of vermicompost (table-9). The starch hydrolyzing microbes at 30,60 and 90 days were $24.20 \times 10^{7}$ c.f.u. $\mathrm{g}^{-1}$ dry soil, $26.10 \times 10^{7}$ c.f.u. $g^{-1}$ dry soil, $22.60 \times 10^{7}$ c.f.u. $\mathrm{g}^{-1}$ dry soil for vermicompost $65 \%$ HHW+35\% CD, $25.70 \times 10^{7}$ c.f.u. $\mathrm{g}^{-1}$ dry soil, $29.00 \times 10^{7}$ c.f.u. $\mathrm{g}^{-1}$ dry soil, $27.00 \times 10$ 7 c.f.u. $\mathrm{g}^{-1}$ dry soil for vermicompost $50 \%$ $\mathrm{HHW}+50 \% \mathrm{CD}$ and $25.00 \times 10^{7}$ c.f.u. $\mathrm{g}^{-1}$ dry soil, $27.00 \times 10^{7}$ c.f.u. $\mathrm{g}^{-1}$ dry soil, 25.20 x $10^{7}$ c.f.u. $\mathrm{g}^{-1}$ dry soil and for vermicompost $35 \% \mathrm{HHW}+65 \% \mathrm{CD}$.

The vermicompost of ratio 50:50 of household waste to cow dung ratio recorded highest starch hydrolyzing population at 60 days $\left(29.00 \times 10^{7}\right.$ c.f.u. $\mathrm{g}^{-1}$ dry soil) while in 
90 days it decreased but maintained higher population than vermicompost 35:65.The vermicompost of ratio 50:50 household waste to cow dung ratio recorded highest c.f.u. count at 90 days followed by the vermicompost 35:65.

The increase in the Starch hydrolyzing microbes at 30 days to 60 days and then decreased up to 90 days in all three types of vermicompost as the days progress towards completion of it. This observations with Starch hydrolyzing bacteria might be due to increase in the organic matter content increased microbial populations in initial stages in later stage the heavy depletion of organic matter content decreased microbial population.

Table.1 Proportion of household waste and cow dung for Vermicomposting

\begin{tabular}{|c|c|cc|}
\hline Windrows & Household waste (w/w) & \multicolumn{2}{|c|}{ Cow dung (w/w) } \\
\hline $\mathbf{1 .}$ & $35 \%(210 \mathrm{Kg})$ & $65 \%$ & $(390 \mathrm{Kg})$ \\
\hline $\mathbf{2 .}$ & $50 \%(300 \mathrm{Kg})$ & $50 \%$ & $(300 \mathrm{Kg})$ \\
\hline $\mathbf{3 .}$ & $65 \%(390 \mathrm{Kg})$ & $35 \%$ & $(210 \mathrm{Kg})$ \\
\hline
\end{tabular}

Table.2 Maximum water holding capacity and bulk density of vermicompost during vermicomposting

\begin{tabular}{|l|c|c|c|c|c|c|}
\hline \multirow{2}{*}{ Windrows compositions } & \multicolumn{3}{|c|}{$\begin{array}{c}\text { Maximum water holding } \\
\text { capacity (\%) }\end{array}$} & \multicolumn{3}{c|}{$\begin{array}{c}\text { Bulk density } \\
\left(\mathbf{M g ~ m}^{-3}\right)\end{array}$} \\
\cline { 2 - 7 } & 30 days & $\mathbf{6 0}$ days & $\mathbf{9 0}$ days & $\mathbf{3 0}$ days & $\mathbf{6 0}$ days & $\mathbf{9 0}$ days \\
\hline HHW 35\% + CD 65 \% & 33.3 & 24.7 & 20.3 & 1.3 & 1.2 & 0.9 \\
\hline HHW 50\% + CD 50 \% & 27.0 & 23.0 & 20.7 & 1.1 & 1.1 & 0.8 \\
\hline HHW 65\% + CD 35 \% & 26.3 & 23.3 & 19.4 & 1.7 & 1.5 & 1.3 \\
\hline
\end{tabular}

Table.3 Total organic carbon, total nitrogen and C: $\mathrm{N}$ ratio of vermicompost during vermicomposting

\begin{tabular}{|c|c|c|c|c|c|c|c|c|c|}
\hline \multirow[t]{2}{*}{ Windrows compositions } & \multicolumn{3}{|c|}{$\begin{array}{l}\text { Total organic carbon } \\
\text { (TOC) } \%\end{array}$} & \multicolumn{3}{|c|}{ Total N (\%) } & \multicolumn{3}{|c|}{$\mathrm{C}: \mathrm{N}$ ratio } \\
\hline & $\begin{array}{c}30 \\
\text { days }\end{array}$ & $\begin{array}{c}60 \\
\text { days }\end{array}$ & $\begin{array}{c}90 \\
\text { days }\end{array}$ & $\begin{array}{c}30 \\
\text { days }\end{array}$ & $\begin{array}{c}60 \\
\text { days }\end{array}$ & $\begin{array}{c}90 \\
\text { days }\end{array}$ & $\begin{array}{c}30 \\
\text { days }\end{array}$ & $\begin{array}{c}60 \\
\text { days }\end{array}$ & $\begin{array}{c}90 \\
\text { days }\end{array}$ \\
\hline HHW 35\% + CD $65 \%$ & 37.20 & 36.10 & 35.20 & 1.49 & 1.53 & 1.91 & 25.00 & 23.50 & 18.43 \\
\hline HHW 50\% + CD $50 \%$ & 37.60 & 35.10 & 34.40 & 1.69 & 2.06 & 2.40 & 22.30 & 17.10 & 14.42 \\
\hline HHW 65\% + CD $35 \%$ & 40.00 & 38.40 & 36.00 & 2.23 & 2.27 & 2.30 & 18.00 & 17.50 & 15.65 \\
\hline
\end{tabular}

Table.4 Total phosphorus and total potassium of vermicompost during vermicomposting

\begin{tabular}{|l|c|c|c|c|c|c|}
\hline Windrows compositions & \multicolumn{3}{|c|}{ Total P (\%) } & \multicolumn{3}{c|}{ Total K (\%) } \\
\cline { 2 - 7 } & 30 days & 60 days & 90 days & 30 days & 60 days & 90 days \\
\hline HHW 35\% + CD 65 \% & 0.29 & 0.81 & 1.12 & 1.20 & 1.42 & 1.66 \\
\hline HHW 50\% + CD 50 \% & 0.31 & 1.00 & 1.34 & 1.41 & 1.63 & 1.79 \\
\hline HHW 65\% + CD 35 \% & 0.36 & 0.84 & 1.13 & 1.23 & 1.33 & 1.37 \\
\hline
\end{tabular}


Table.5 Microbial biomass carbon, microbial biomass nitrogen and microbial biomass phosphorus of vermicompost during vermicomposting

\begin{tabular}{|c|c|c|c|c|c|c|c|c|c|}
\hline \multirow[t]{2}{*}{ Windrows compositions } & \multicolumn{3}{|c|}{$\begin{array}{l}\text { Microbial biomass } \\
\text { carbon }\left(\mu \mathrm{g} \mathrm{g}^{-1}\right)\end{array}$} & \multicolumn{3}{|c|}{$\begin{array}{l}\text { Microbial biomass } \\
\text { nitrogen }\left(\mu \mathrm{g} \mathrm{g}^{-1}\right)\end{array}$} & \multicolumn{3}{|c|}{$\begin{array}{l}\text { Microbial biomass } \\
\text { phosphorus }\left(\mu \mathrm{g} \mathrm{g}^{-1}\right)\end{array}$} \\
\hline & $\begin{array}{c}30 \\
\text { days }\end{array}$ & $\begin{array}{c}60 \\
\text { days }\end{array}$ & $\begin{array}{c}90 \\
\text { days }\end{array}$ & $\begin{array}{c}30 \\
\text { days }\end{array}$ & $\begin{array}{c}60 \\
\text { days }\end{array}$ & $\begin{array}{c}90 \\
\text { days }\end{array}$ & $\begin{array}{c}30 \\
\text { days }\end{array}$ & $\begin{array}{c}60 \\
\text { days }\end{array}$ & $\begin{array}{c}90 \\
\text { days }\end{array}$ \\
\hline HHW 35\% + CD $65 \%$ & 266 & 308 & 289 & 200 & 196 & 193 & 13.30 & 16.00 & 16.30 \\
\hline HHW $50 \%$ + CD $50 \%$ & 278 & 322 & 298 & 214 & 208 & 198 & 13.90 & 17.00 & 17.80 \\
\hline HHW 65\% + CD $35 \%$ & 196 & 285 & 270 & 192 & 190 & 187 & 14.00 & 14.25 & 14.50 \\
\hline
\end{tabular}

Table.6 Water soluble carbon, hot water soluble carbon and acid hydrolysable carbohydrate of vermicompost during vermicomposting

\begin{tabular}{|c|c|c|c|c|c|c|c|c|c|}
\hline \multirow[t]{2}{*}{ Windrows compositions } & \multicolumn{3}{|c|}{$\begin{array}{c}\text { Water soluble carbon } \\
\left(\mathrm{g} \mathrm{kg}^{-1}\right)\end{array}$} & \multicolumn{3}{|c|}{$\begin{array}{l}\text { Hot-water soluble } \\
\text { carbon }\left(\mathrm{g} \mathrm{kg}^{-1}\right)\end{array}$} & \multicolumn{3}{|c|}{$\begin{array}{l}\text { Acid hydrolysable } \\
\text { carbohydrate }\left(\mathrm{mg} \mathrm{kg}^{-1}\right)\end{array}$} \\
\hline & $\begin{array}{c}30 \\
\text { days }\end{array}$ & $\begin{array}{c}60 \\
\text { days }\end{array}$ & $\begin{array}{c}90 \\
\text { days }\end{array}$ & $\begin{array}{c}30 \\
\text { days }\end{array}$ & $\begin{array}{c}60 \\
\text { days }\end{array}$ & $\begin{array}{c}90 \\
\text { days }\end{array}$ & $\begin{array}{c}30 \\
\text { days }\end{array}$ & $\begin{array}{c}60 \\
\text { days }\end{array}$ & $\begin{array}{c}90 \\
\text { days }\end{array}$ \\
\hline HHW 35\% + CD $65 \%$ & 0.059 & 0.063 & 0.066 & 0.508 & 0.520 & 0.532 & 40.22 & 41.55 & 40.88 \\
\hline HHW 50\% + CD $50 \%$ & 0.071 & 0.077 & 0.081 & 0.530 & 0.542 & 0.550 & 80.21 & 85.21 & 83.17 \\
\hline HHW $65 \%$ + CD $35 \%$ & 0.048 & 0.053 & 0.057 & 0.426 & 0.436 & 0.471 & 22.06 & 26.06 & 24.06 \\
\hline
\end{tabular}

Table.7 $\mathrm{KMnO}_{4}$-carbon, organic carbon and dehydrogenase activity of vermicompost during vermicomposting

\begin{tabular}{|c|c|c|c|c|c|c|c|c|c|}
\hline \multirow[t]{2}{*}{$\begin{array}{l}\text { Windrows } \\
\text { compositions }\end{array}$} & \multicolumn{3}{|c|}{$\begin{array}{c}\mathrm{KMnO}_{4}-\text { carbon } \\
\left(\mathrm{g} \mathrm{kg}^{-1}\right)\end{array}$} & \multicolumn{3}{|c|}{$\begin{array}{l}\text { Organic carbon } \\
\qquad\left(\mathrm{g} \mathrm{kg}^{-1}\right)\end{array}$} & \multicolumn{3}{|c|}{$\begin{array}{c}\text { Dehydrogenase } \\
\text { activity } \\
\left(\mu \mathrm{g} \mathrm{TPF}^{-1} \mathrm{~g}^{-1} \mathrm{soil}^{-1}\right)\end{array}$} \\
\hline & $\begin{array}{c}\text { 30 } \\
\text { days }\end{array}$ & $\begin{array}{c}\mathbf{6 0} \\
\text { days }\end{array}$ & $\begin{array}{c}90 \\
\text { days }\end{array}$ & $\begin{array}{c}\text { 30 } \\
\text { days }\end{array}$ & $\begin{array}{c}60 \\
\text { days }\end{array}$ & $\begin{array}{c}90 \\
\text { days }\end{array}$ & $\begin{array}{c}30 \\
\text { days }\end{array}$ & $\begin{array}{c}60 \\
\text { days }\end{array}$ & $\begin{array}{c}90 \\
\text { days }\end{array}$ \\
\hline HHW 35\% + CD $65 \%$ & 5.79 & 5.32 & 5.01 & 178.40 & 103.70 & 97.60 & 6.99 & 7.31 & 7.82 \\
\hline HHW 50\% + CD $50 \%$ & 6.25 & 5.97 & 5.42 & 186.20 & 129.10 & 117.00 & 8.00 & 8.42 & 8.96 \\
\hline HHW 65\% + CD $35 \%$ & 5.56 & 5.06 & 4.75 & 175.80 & 116.40 & 105.00 & 6.42 & 6.92 & 7.12 \\
\hline
\end{tabular}

Table.8 Bacillus, pseudomonas and phosphate solubilizing bacteria populations during vermicomposting

\begin{tabular}{|c|c|c|c|c|c|c|c|c|c|}
\hline \multirow[t]{2}{*}{$\begin{array}{l}\text { Windrows } \\
\text { compositions }\end{array}$} & \multicolumn{3}{|c|}{$\begin{array}{c}\text { Bacillus } \\
\text { (x 10 }{ }^{7} \text { c.f.u. } g^{-1} \text { drysoil) }\end{array}$} & \multicolumn{3}{|c|}{$\begin{array}{c}\text { Pseudomonas } \\
\text { (x 107 c.f.u. } \text { g }^{-1} \text { drysoil) }\end{array}$} & \multicolumn{3}{|c|}{$\begin{array}{c}\text { Phosphate solubilizing } \\
\text { bacteria } \\
\text { (x } 10^{7} \text { c.f.u. } \text { g }^{-1} \text { drysoil ) }\end{array}$} \\
\hline & $\begin{array}{c}30 \\
\text { days }\end{array}$ & $\begin{array}{c}60 \\
\text { days }\end{array}$ & $\begin{array}{c}90 \\
\text { days }\end{array}$ & $\begin{array}{c}\text { 30 } \\
\text { days }\end{array}$ & $\begin{array}{c}\mathbf{6 0} \\
\text { days }\end{array}$ & $\begin{array}{c}90 \\
\text { days }\end{array}$ & $\begin{array}{c}30 \\
\text { days }\end{array}$ & $\begin{array}{c}60 \\
\text { days }\end{array}$ & $\begin{array}{c}90 \\
\text { days }\end{array}$ \\
\hline HHW 35\% + CD $65 \%$ & 35.30 & 34.60 & 31.10 & 27.90 & 29.50 & 27.50 & 32.90 & 34.90 & 30.50 \\
\hline HHW 50\% + CD $50 \%$ & 35.10 & 37.00 & 36.00 & 29.00 & 33.00 & 30.50 & 31.70 & 36.30 & 35.00 \\
\hline HHW 65\% + CD $35 \%$ & 34.00 & 33.80 & 28.00 & 27.00 & 28.80 & 23.10 & 30.00 & 34.20 & 31.10 \\
\hline
\end{tabular}


Table.9 Starch hydrolyzing microbes and cellulose hydrolyzing bacteria populations during vermicomposting

\begin{tabular}{|c|c|c|c|c|c|c|}
\hline \multirow[t]{2}{*}{ Windrows compositions } & \multicolumn{3}{|c|}{$\begin{array}{l}\text { Starch hydrolyzing microbes } \\
\left(\text { (x } 10^{7} \text { c.f.u. } \mathrm{g}^{-1} \text { drysoil }\right)\end{array}$} & \multicolumn{3}{|c|}{$\begin{array}{l}\text { Cellulose hydrolyzing bacteria } \\
\left(\begin{array}{l}\left.\text { (x } \mathbf{1 0}^{7} \text { c.f.u. } \mathrm{g}^{-1} \text { drysoil }\right)\end{array}\right.\end{array}$} \\
\hline & $\begin{array}{c}30 \\
\text { days }\end{array}$ & $\begin{array}{c}60 \\
\text { days }\end{array}$ & $\begin{array}{c}90 \\
\text { days }\end{array}$ & $\begin{array}{c}30 \\
\text { days }\end{array}$ & $\begin{array}{l}60 \\
\text { days }\end{array}$ & $\begin{array}{c}90 \\
\text { days }\end{array}$ \\
\hline HHW 35\% + CD $65 \%$ & 25.00 & 27.00 & 26.00 & 23.20 & 25.20 & 22.80 \\
\hline HHW $50 \%$ + CD $50 \%$ & 25.70 & 29.00 & 27.00 & 24.60 & 26.50 & 25.10 \\
\hline HHW $65 \%+$ CD $35 \%$ & 24.20 & 26.10 & 22.60 & 22.40 & 24.50 & 21.90 \\
\hline
\end{tabular}

Table.10 Azotobacter and azospirillum populations during vermicomposting

\begin{tabular}{|c|c|c|c|c|c|c|}
\hline \multirow[t]{2}{*}{ Windrows compositions } & \multicolumn{3}{|c|}{$\begin{array}{c}\text { Azotobacter } \\
\left(x \mathbf{1 0}^{7} \text { c.f.u. } \mathrm{g}^{-1} \text { drysoil }\right)\end{array}$} & \multicolumn{3}{|c|}{$\begin{array}{c}\text { Azospirillum } \\
\left(\mathbf{x} 10^{7} \text { c.f.u. } g^{-1} \text { drysoil }\right)\end{array}$} \\
\hline & 30 days & 60 days & 90 days & 30 days & 60 days & 90 days \\
\hline HHW 35\% + CD $65 \%$ & 26.00 & 29.30 & 27.10 & 27.50 & 29.00 & 23.50 \\
\hline HHW $50 \%$ + CD $50 \%$ & 24.80 & 30.00 & 29.00 & 28.30 & 31.00 & 25.00 \\
\hline HHW 65\% + CD $35 \%$ & 25.00 & 28.10 & 27.00 & 26.00 & 28.60 & 21.10 \\
\hline
\end{tabular}

Table.11 Vermicompost recovery (\%) after 90 days vermicomposting.

\begin{tabular}{|c|c|c|c|}
\hline $\begin{array}{c}\text { Windrows } \\
\text { compositions }\end{array}$ & $\begin{array}{c}\text { Dry weight of } \\
\text { substrate } \\
\text { (kg) }\end{array}$ & $\begin{array}{c}\text { Dry weight of final } \\
\text { prepared } \\
\text { vermicompost (kg) }\end{array}$ & Recovery percentage (\%) \\
\hline HHW 35\% + CD 65 \% & 210.00 & 122.49 & 58.33 \\
\hline HHW 50\% + CD 50 \% & 210.00 & 132.30 & 63.00 \\
\hline HHW 65\% + CD 35 \% & 210.00 & 85.39 & 40.66 \\
\hline
\end{tabular}

Cellulose hydrolyzing bacteria (x $10^{7}$ c.f.u. $\mathrm{g}^{-1}$ dry soil)

The cellulose hydrolyzing bacteria increased from 30 days to 60 days during the preparation of vermicompost as shown in the table-9.The cellulose hydrolyzing microbes at 30,60 and 90 days were $22.40 \times 10^{7}$ c.f.u. $\mathrm{g}^{-1}$ dry soil, $24.50 \times 10^{7}$ c.f.u. $\mathrm{g}^{-1}$ dry soil, $21.90 \times 10^{7}$ c.f.u. $\mathrm{g}^{-1}$ dry soil for vermicompost $65 \% \mathrm{HHW}+35 \% \mathrm{CD}, 24.60 \mathrm{x}$ $10^{7}$ c.f.u. $\mathrm{g}^{-1}$ dry soil, $26.50 \times 10^{7}$ c.f.u. $\mathrm{g}^{-1}$ dry soil, $25.10 \times 10^{7}$ c.f.u. $\mathrm{g}^{-1}$ dry soil for vermicompost $50 \% \mathrm{HHW}+50 \% \mathrm{CD}$ and $23.20 \times 10^{7}$ c.f.u. $\mathrm{g}^{-1}$ dry soil, $25.20 \times 10^{7}$ c.f.u. $\mathrm{g}^{-1}$ dry soil, $22.80 \times 10^{7}$ c.f.u. $\mathrm{g}^{-1}$ dry soil for vermicompost $35 \% \mathrm{HHW}+65 \%$ CD.

The vermicompost of ratio 50:50 of household waste to cow dung ratio recorded highest cellulose hydrolyzing bacteria at 60 days i.e. $6.50 \times 10^{7}$ c.f.u. $\mathrm{g}^{-1}$ dry soil while in 90 days it decreased but maintained higher population than vermicompost 35:65.

The increase in the Cellulose hydrolyzing microbes was seen from 30 days to 60 days and then decreased up to 90 days in all types of vermicompost as the days progress towards completion of it. This observation with Cellulose hydrolyzing microbes might be due 
to increase in the organic matter content increased microbial populations in initial stages in later stage the heavy depletion of organic matter content decreased microbial population.

\section{Azotobacter (x $10^{7}$ c.f.u. $g^{-1}$ dry soil)}

The azotobacter population increased from 30 days to the 60 days during the preparation of vermicompost (table-10). The azotobacter population at 30, 60 and 90 days were 25.00 x $10^{7}$ c.f.u. $\mathrm{g}^{-1}$ dry soil, $28.10 \times 10^{7}$ c.f.u. $\mathrm{g}^{-1}$ dry soil, $27.00 \times 10^{7}$ c.f.u. $\mathrm{g}^{-1}$ dry soil for vermicompost $65 \% \mathrm{HHW}+35 \% \mathrm{CD}, 24.80$ x $10^{7}$ c.f.u. $\mathrm{g}^{-1}$ dry soil, $30.00 \times 10^{7}$ c.f.u. $\mathrm{g}^{-1}$ dry soil, $29.00 \times 10^{7}$ c.f.u. $\mathrm{g}^{-1}$ dry soil for vermicompost $50 \% \mathrm{HHW}+50 \% \mathrm{CD}$ and $26.00 \times 10^{7}$ c.f.u. $\mathrm{g}^{-1}$ dry soil, $29.30 \times 10^{7}$ c.f.u. $\mathrm{g}^{-1}$ dry soil, $27.10 \times 10^{7}$ c.f.u. $\mathrm{g}^{-1}$ dry soil and for vermicompost $35 \% \mathrm{HHW}+65$ $\% \mathrm{CD}$.

The vermicompost prepared of household waste to cow dung ratio 50:50 recorded highest azotobacter population at 60 days (24.80 x $10^{7}$ c.f.u. $\mathrm{g}^{-1}$ dry soil) while in 90 days it decreased but maintained higher population than vermicompost 35: 65 .

The increase in the azotobacter population from 30 days to 60 days and then decreased at 90 days in all three types of vermicompost as the days progress towards completion. It might be due to increase in the organic matter content increased microbial populations in initial stages in later stage the heavy depletion of organic matter results decrease in microbial activities.

\section{Azospirillum (x $10{ }^{7}$ c.f.u. $\mathrm{g}^{-1}$ dry soil)}

The azospirillum population increased from 30 days to 60 days and decreased at 90 days during the preparation of vermicompost (table-10). The azospirillum population at 30, 60 and 90 days were $26.00 \times 10^{7}$ c.f.u. $\mathrm{g}^{-1}$ dry soil, $28.60 \times 10^{7}$ c.f.u. $\mathrm{g}^{-1}$ dry soil, $21.10 \times 10$ 7 c.f.u. $\mathrm{g}^{-1}$ dry soil for vermicompost $65 \%$ HHW $+35 \% \mathrm{CD}, 28.30 \times 10^{7}$ c.f.u. $\mathrm{g}^{-1}$ dry soil, $31.00 \times 10^{7}$ c.f.u. $g^{-1}$ dry soil, $25.00 \times 10$ 7 c.f.u. $\mathrm{g}^{-1}$ dry soil for vermicompost $50 \%$ $\mathrm{HHW}+50 \% \mathrm{CD}$ and $27.50 \times 10^{7}$ c.f.u. $\mathrm{g}^{-1}$ dry soil, $29.00 \times 10^{7}$ c.f.u. $\mathrm{g}^{-1}$ dry soil and $23.50 \times 10^{7}$ c.f.u. $\mathrm{g}^{-1}$ dry soil for vermicompost $35 \% \mathrm{HHW}+65 \% \mathrm{CD}$.

The vermicompost prepared from the equal proportion of household waste to cow dung recorded highest azospirillum population at 60 days $31.00 \times 10^{7}$ c.f.u. $\mathrm{g}^{-1}$ dry soil while in 90 days it decreased but maintained higher population than vermicompost 35:65.

The increase in the azospirillum population was seen from 30 days to 60 days and then decreased at 90 days in all types of vermicompost as the days progress towards completion of it, might be due to increase in the organic matter content increased microbial populations in initial stages in later stage the heavy depletion of organic matter decreased microbial activities.

\section{Vermicompost recovery $(\%)$}

The vermicompost recovery (table-11) showed a declined pattern range from 63.00 $\%$ to $40.66 \%$ in case of all the three proportions of vermicomposts. The vermicompost of ratio (50:50) of household waste and cow dung recorded highest recovery percent (63.00), while the lowest recovery percent was observed in the vermicompost of ratio (65: 35). The vermicompost (50:50) recorded highest recovery as the equal proportion was favorable for the maximum earthworm activities, thus more amount of substrate and cow dung converted to vermicompost. 
Whereas, lowest recovery percentage (40.66) was recorded for 65: 35 ratio. The finding was in tune with the observation of Sharma (2015).

\section{Acknowledgement}

We are very much thankful to Department Of Soil Science, Dr. Rajendra Prasad central agricultural university, Pusa, Samastipur, Bihar for providing excellent lab facilities and helping environment for smooth completion of our project in time.

\section{References}

Araujo, Y., Luizão, F. and Barros, E. (2004) Effect of earthworm addition on soil nitrogen availability, microbial biomass and litter decomposition in mesocosms. Biology and Fertility of Soils 39(3), 146152.

Black, C.A. (1965) Methods of soil analysis Part I. American Society of Agronomy Inc. Publications. Madison Wiscons in USA.

Blair, G.J., Lefroy, R.D.B., and Lise, L. (1995) Soil carbon fractions based on their degree of oxidation, and the development of a carbon management index for agricultural systems. Australian Journal Agricultural Resources 46(7), 1459-1466.

Brookes, P.C., Kragt, J.F., Powlson, D.S. and Jenkinson, D.S. (1985) Chloroform fumigation and release of soil $\mathrm{N}$ : A rapid direct extraction method to measure biomass $\mathrm{N}$ in soil, Soil Biochemistry 17(6), 837-842.

Brookes, P.C., Powlson, D.S. and Jenkinson, D.S. (1982) Measurement of microbial biomass phosphorous in soils. Soil Biology and Biochemistry 14, 319-321.

Chaudhuri, P.S., Pal, T.K., Bhattacharjee, G. and Dey, S.K. (2000) Chemical changes during vermicomposting of kitchen wastes. Tropical Ecology 41(1), 107110.

Cheshire, M.V. and Mundie, C.M. (1966) The hydrolytic extraction of carbohydrates from soil by sulphuric acid. Journal of Soil Science 17(2), 372-381.

Chiranjeeb K, Prasad S.S., Singh S.P, Bharati $\mathrm{V}$ and Jha S. Effect of Household Vermicompost and Fertilizer on Soil Microbial Biomass Carbon, Biomass Phosphorus and Biomass Nitrogen in Incubation Experiment. Int.J.Curr.Microbiol.App.Sci. $\quad 2020$; 9(02): 1508-1516

Elvira, C., Goicoechea, M., Sampedro, L., Mato, S and Nogales, R. (1996) Bioconversion of solid paper pulp mill sludges by earthworms. Bioresource Technology 57(2), 173-177.

Fertilizer Control Order (1985) Biofertilizers and organic fertilizers in Fertilizer (control) order, 1985. Published by National Centre of Organic Farming, Dept. of Agriculture and Corporation, Ministry of Agriculture, Govt. of India.

Garg, V.K. and P. Kaushik, (2004) Dynamics of biological and chemical parameter during vermicomposting of solid textile mill sludge mixed with cow dung and agricultural residues. Bioresource Technology 94(2), 203-209.

Ghani, A., Dexter, M. and Perrott, K.W. (2003) Hot-water extractable carbon in soils: sensitive measurement for determining impacts of fertilisation, grazing and culti-vation. Soil Biology and Biochemistry 35(9), 1231-1243.

Klein, D. A., Loh, T.C. and Coudling, R.L. (1971) A rapid procedure to evaluate dehydrogenase activity of soils low in organic matter. Soil Biology Biochemistry 3(4), 385-387

Krishnamoorthy, R.V. (1990) Mineralization of phosphorous by faecal phosphates of some earthworms of Indian tropics. 
Proceedings of the Indian Academy of Sciences Animal Sciences 99(6), 509518.

McGill, W.B., Cannon, K.R., Robertson, J.A. and Cook, F.D. (1986) Dynamics of soil microbial biomass and water-soluble organic $\mathrm{C}$ in Breton $\mathrm{L}$ after 50 years of cropping to two rotations. Canadian Journal of Soil Science 66(1), 1-19.

Nath, G., Singh, K. and Singh, D.K. (2009) Chemical analysis of vermicomposts vermiwash of different combinations of animal, agro and kitchen wastes. Australian Journal of Basic and Applied Sciences 3(4), 3672-3676.

Nelson, D.W. and Sommers, L.E. (1982) Total carbon, organic carbon and organic matter: In: A.L. Page, R.H. Miller and D.R. Keeney) Methods of soil analysis. Part 2 Chemical and Microbiological properties 539-579.

Pattnaik, S. and Reddy, M.V. (2009) Bioconversion of Municipal (Organic) Solid Waste into Nutrient-rich Vermicompost by Earthworms (Eudriluseugeniae, Eiseniafetida and Perionyx excavates). Dynamic Soil Dynamic Plant 3, 122-128.

Pattnaik, S., and Reddy, M.V. (2011) Microbial characterization of vermicompost and compost of urban waste processed by three earthworm species - E. eugeniae, E. fetida and $P$. excavatus. Pedobiologia, Under review. Piper, C.S. (1966) Soil and plant analysis.Hans publishers, Bombay, 401.

Schmidt, E.L. and Caldwell, A.C. (1967) A practical manual of Soil Microbiology Laboratory Methods. Food and Agriculture Organization of the United Nations. Soils Bulletin, 72-75.

Sharma, A. (2015) Production of Enriched Vermicompost and Their Evaluation on Growth and Yield of Chickpea (Cicer arietinum L.).M.Sc. (Agri.) Thesis, Jawaharlal Nehru Krishi Vishwa Vidyalaya, Jabalpur.

Tripathi, G. and P. Bhardwaj.(2004) comparative studies on biomass production, life cycle and composting efficiency of Eiseniafoetida (savigny) and Lampitomauittii (Kinberg). Bioresoure Technology 92(3), 275-283.

Vance, E.D., Brookes, P.C. and Jenkinson, D.S. (1987) An extraction method for measuring soil biomass carbon C. Soil Biology and Biochemistry 19(6), 703707.

Walkly, A., Black, I.A. (1934) An examination of the Degtjareff method for determining organic carbon in soil: Effect of variations in digestion conditions and of inorganic soil constituents. Soil Science 63, 251-263.

\section{How to cite this article:}

Kumar Chiranjeeb and Prasad, S. S. 2020. Preparation of Quality Enriched Vermicompost and its Analysis. Int.J.Curr.Microbiol.App.Sci. 9(07): 3556-3571.

doi: https://doi.org/10.20546/ijcmas.2020.907.416 